УДК 811.111

DOI https://doi.org/10.32838/2663-6069/2020.2-2/27

Labunets Yu. O.

Borys Grinchenko Kyiv University

\title{
THE INFLUENCE OF ARTISTIC DISCOURSE ON THE FORMATION OF STUDENTS' MOTIVATION TO LEARN A FOREIGN LANGUAGE THROUGH THE REPRESENTATION OF THE AUTHOR'S WORLDVIEW
}

The article analyzes definitions, features and main characteristics of discourse in general and artistic discourse that could be used to learn foreign language in particular. In particular, the author briefly considers the nature of artistic discourse and its cognitive and communicative aspects. This type of artistic discourse in terms of influencing the secondary linguistic personality's motivational sphere is interpreted by the author as a mental-communicative interaction between the author and the reader, embodied in the texts of art works. The author sees a significant impact of discourse on the motivational processes of the human's worldview, and in the context of artistic discourse we note its influence through the reflection of the author's world view picture of the world on the formation of positive motivation (both external and internal).This article deals with the problem of artistic discourse influence through the representation of author's worldview from a motivational angle. The main approaches to the study of discourse are considered from several angles. Using influence of artistic discourse as a powerful impact background for students' foreign language competence formation for the conscious acquisition of foreign language competence and the formation of a secondary linguistic personality is the up-to-date possibility to brush up language learning process especially for foreign languages. In the course of artistic discourse research of foreign sources it is necessary to adhere to the combined discourse analysis as the most optimal pedestrian in the context of positive influence on the secondary linguistic personality's motivational sphere. The motivation growth towards the target language learning is defined and discussed, and for that, the usage of foreign artistic discourse examples is necessary. Data is collected from empirical research, method of involved observation, interviews and years of working as a senior lecturer at the Foreign Language and Methodology Department. From this point of view author put the emphasize on the importance of author's artistic discourse creation strategies understanding as a strong impact factor on motivation to self-improvement.

Key words: discourse, artistic discourse, foreign language artistic discourse, reflection of the author's worldview, secondary linguistic personality, author's linguistic personality, motivation to study a foreign language.

Introduction. The defining characteristic of modern informatized society is the rapid development of all human activity spheres, which requires from the individual readiness for adequate change, adaptation, rapid reorientation in new conditions and readiness for permanent self-improvement. In the context of students' foreign language training of an important aspect of learning is the formation of secondary language personality based on foreign language discourse and in particular artistic discourse, when the author's language personality is not only an important component in understanding his work, but also demonstrates the result of mental activity, which reflects the author's picture of the world and contributes to the multifaceted formation of foreign language communicative competence and in accordance with our scientific research has an extraordinary motive potential.

The question of modern means and factors influencing the individual's positive motivation to the foreign languages learning that is up-to-date issue that is valuable not only for educational institutions, but directly or indirectly for most areas of modern society, and linguistic researches in particular. The Internet with a particularly powerful core of social media platform discourse platforms (Instagram, Facebook, Linkdin) occupie an increasingly prominent place in the processes of testing, optimization, modification, internalization, mimicry of discourse, and are the best platforms for monitoring a variety of policies, monitoring advertisement, literary, film discourse, along with discourse in the field of public relations). 
Thus, the survey in this aspect of the language learning process is relevant in accordance with permanent linguistic and cultural changes and processes of intercultural and cross-cultural interaction and is especially important today, when students gradually lose motivation to learn, including formal and academic communicative strategies and influence the multidisciplinary discourse of various spheres of society.

Analysis of resent achievements and publications. Language has served humanity for centuries as a social phenomenon and a tool with unlimited properties that can meet the individual's needs in aspects of communication and cognition. In this context, the aspect of the linguistic personality's phenomenon is an important focus of modern linguistic picture of the world. Thus, the phenomenon of linguistic personality was studied by linguists, psychologists and linguistic didactics. In particular J. Weisgerber and V. Vinogradov considered the linguistic personality in a narrow aspect, as the author's linguistic personality in art work and the character's linguistic personality [5]. Psychologist O. Leontiev defined the speaker as a linguistic personality, the creator of the world image. The phenomenon of language personality was studied by: G. Bogin, who developed a language personality's model as a person who is ready to produce speech actions, to create speech products; Yu. Prokhorov identified and studied the features of speech and speech personality; T. Snytko considered the differences in the definition of the "linguistic personality" concept of Western and Eastern cultures; V. Karasyk introduced the concept of "dictionary language personality"; O. Bilyaev researched the concept of "national-linguistic personality"; L. Matsko, S. Yermolenko defined a nationally-conscious Ukrainian-speaking personality; L. Skuratovsky studied the spiritual linguistic personality [5].

In psycholinguistics, intercultural communication and foreign language teaching discurse is developing as an independent direction as the secondary linguistic personality's formation. In particular M. Kolpakova, O. Leontovych, I. Khaleeva and K. Khitryk consider the secondary linguistic personality as one that masters another perception of the "linguistic picture of the world", which makes it possible to understand the new culture [3].

The essence of culture phenomenon is dialogical: man as its producer is not only homo sapiens, but also necessarily homo communicans, entering into dialogical relations with the world and with already functioning in it models of culture and creates new ones.
In the process of literary texts dialogical interaction in the system there are relations of mutual influence or debatable negation, as a result of which in both cases there are newly created texts of fiction. Verbal and artistic texts as verbal signs of culture preserve the cultural memory of the ages, because "the text by its nature is characterized by a certain encoding" $[11$, p. 4]. Therefore, Elmslev defined the text as everything that was, is and will be said in a certain language, that is, the text, in contrast to language as a closed system, is a system that is constantly increasing in time and that is something that has tendency to influence students' motivation in the process of foreign language learning by accepting themselves as active participates of this modern discourse art [6].

The text as the written form of discourse leading in Internet sphere in the context of discourse and intertextuality and according to the theory of intertext and creative activity is carried out by both the author and the reader. Intertextuality in the verbal expression of linguistic and cultural codes testifies to the continuous procedurality of artistic texts. Intertext becomes a material expression of linguistic and cultural codes of artistic discourse and a place of their manifestation.

Appealing to the influence of artistic discourse and intertextualities that dealt with the aspect of discourse in the linguistic picture of the world there were several scientist (N. Arutyunova, F. Batsevich, V. Buryak, N. Volkogon, V. Zvegintsev, V. Karasyk, S. Konovets, O. Onufrienko, I. Sobolev, G. Pocheptsov, R. Bart, W. Eco, Y. Lotman, J. Searle, M. Foucault, I. Stern) that took part in developing this system. But to this day this phenomenon with increasing roles, functions and characteristics are still the subject of active interest of scientists in various fields $[1 ; 2 ; 3 ; 4 ; 6 ; 11]$.

The objective of the article. Therefore, the purpose of our scientific research could be defined as:

1) identification of the main artistic discourse features and foreign artistic discourse in particular as a product of human activity;

2) definition of foreign language artistic discourse, which contributes to the formation of students' positive motivation to learn a foreign language through the reflection of the author's worldview. This goal involves solving the following tasks:

- to analyze the concept of "artistic discourse";

- to establish language parameters and means of interpretation of the specified term;

- apply a linguocultural approach to the interpretation of artistic discourse and internalization as a sign of linguistic and cultural codes of a certain era and the author's picture of the world. 
The material and the methods. The term "artistic discourse" is a widespread and pervasive aspect of a significant number of modern linguistic intelligence, which does not have the comprehensive definition today, which can be explained by the multifaceted nature of this concept. As for discourse in general, the most important category of discourse can be considered intertextuality. "The discourse of oral prose text, which reflects stereotypical attitudes, assessments, logic of the story, is not limited to one story, it includes other previous texts, exchange of views..." [3, p. 40]. Each type of discourse has its own, unique system-acquired categories, which in the discourse of another type will be system-neutral. Linguistic study of the which task is to identify not only the linguistic inventory, but also the ratio of linguistic and extralinguistic factors in the creation of a particular linguistic work, is multifaceted. One of the directions of such analysis is the theory of discourse $[1 ; 3 ; 4]$.

The concept of discourse (from the Latin discursus - reasoning) was formed during the crisis of structuralism and early poststructuralist philosophy (late 60 's - early 70's). Z. Harris played important role in this process by attempts to extend the distributive method to a coherent text and involve in its description of the socio-cultural situation [3].

In the linguistics of the text in 1970s, the terms "discourse" and "text" were usually identified, due to the lack of a word in some European languages equivalent to the Franco-English "discourse", which had to be replaced by "text". However, in the late 70 's - early. In the 1980 's, the tendency to differentiate between them became noticeable, so at first the distinction between the aspects they represented was used: discourse - social, and the text - linguistic [3, p. 30].

The active development of discourse theory in the 1970's and 1980's was caused by dissatisfaction with only structural methods of text research. Traditionally, discourse means "a coherent text in conjunction with extralinguistic - pragmatic, socio-cultural, psychological and other factors; the text taken in the aspect of events; speech, which is seen as a purposeful social action, as a component that participates in the interaction of people and the mechanisms of their consciousness (cognitive processes). Discourse is "speech immersed in life" [3, p. 136-137].

Discourse theory is a direction of linguistics at the present stage, which is actively developing in the theoretical and empirical planes, in the study of live speech in the process of live communication, when a person appears in the center of research. The latest theory of discourse is a synthesis of knowledge and research results in the field of socio-cultural fields. Of particular importance and importance are scientific investigations in the direction of studying this type of discourse as "artistic discourse".

The significant impact of artistic discourse on the formation of students' motivation to learn a foreign language in accordance with my research topic: we analyzed the motivational components of students in the first (2019) and second year (2020) at the Pedagogical Institute and Institute of Arts to learn a foreign language. Among all the students that have taken part in the research there were 90 students in faculties of "Preschool Education" and "Primary Education" of the Pedagogical Institute and 90 students in "Design", "Fine Arts", "Choreography" and "Music" at Institute of Arts at Borys Grinchenko Kiev University. Around $69 \%$ of students noted a positive impact by completing tasks with authentic foreign sources (adapted and unadapted authentic sources at the first bachelor's level) to increase internal motivation and help students build their own education. on the strategy of improving foreign language communicative competence.

The psychology of motivation is a widely studied problem of modern psychology and related science; it is due to the exceptional complexity, heterogeneity and variability of the motivation phenomenon, as well as its hidden from the direct perception of the observer and often even from the consciousness of the subject activities [34]. According to the activity approach, the satisfaction of needs occurs through activity as the process of active interaction with the surrounding reality, when a person acts as a subject that purposefully influences the object [3]. One of the main structural elements of activity is the motive: 1) material or ideal "object", which motivates and directs the activity or action, the meaning of which is that the motives meet certain needs of the subject; 2) the mental image of the subject [11].

Significant influence on motivational processes is exerted by the picture of the human's world, and in the context of artistic discourse we note its influence through the reflection of the author's picture of the world on the formation of positive motivation (both external and internal) and the integrity of perception of reality in foreign language education [6]. In terms of structure, discourse is a two-way formation that has a plan of expression (a sequence of language units that was created in a certain place, at a certain time and for a certain purpose) and a plan of content (formed by the interaction of its semantics and pragmatics). In our exploration, we consider 
artistic discourse as a communicative act, as a set of speech-thinking actions of communicators related to the cognition, comprehension and presentation of the world by the addressee and comprehension of his linguistic picture of the world by the recipient. That is why the purpose of artistic discourse could be defind as the writer's influence on the system of values, knowledge and beliefs of the reader through his work $[2 ; 3 ; 9]$.

The artistic text is characterized by the presence of tropes and comparisons which makes it more sophisticated. The second distinguishing feature of artistic discourse is its purpose of the author's desire to influence the reader through his work. Artistic discourse is characterized by a variety of genre, thematic, age and ideological components. It is established that artistic discourse consists of many "sub-discourses" (political, diplomatic, medical, etc.), due to which a variety of thread of the work [7]. Affect of resence is important for an artistic text creative in-house activities. Anthropocentrism is another useful characteristic of artistic discourse to use in the field of motivation (man in the center of the plot space: man, his thoughts, feelings, experiences, relationships are reflected in reality through the prism of thoughts and experiences and occupy a central place in artistic discourse) [2].

Thus, a literary text has personality traits, because it is a constant set of signs and a carrier of a certain content, but each reader can see in it different information. This is a special kind of communication, which is characterized by the uniqueness of each individual piece of art [7;8]. Artistic discourse is always communicatively oriented, because it is a certain message of the writer to the reader.

Scientist Y. Lotman, based on communicators and recipients, identifies 5 levels of communication in artistic discourse:

1. Communication between the author and the reader (the text is a message).

2. Communication between the audience and cultural heritage (the text is a carrier of cultural memory).

3. The reader's communication with himself (the text is a prism through which the reader has the opportunity to discover new aspects of their own personality and determine their own view of the world around them).

4. The reader's communication with the text (the text is an independent unit that has its own position in the dialogue).

5. Communication between the text and the cultural context (cultural context is a multilevel unit that allows the text to interact at different levels) $[2 ; 4 ; 9]$.

The study of artistic discourse is closely linked to the study of the author's personality, his individual style and language. The concept of "linguistic personality" was introduced by Y. Karaulov, who gives it the following definition: "It is a set of abilities and characteristics of man that determine the creation and perception of speech works (texts), which is determined by the target orientation" [1, p. 230].

The phenomenon of linguistic personality was studied by linguists, psychologists and language teachers. J. Weisgerber and V. Vinogradov considered the linguistic personality in a narrow aspect as the linguistic personality of the author of the art work and the linguistic personality of the character. Psychologist $\mathrm{O}$. Leontiev defined the speaker as a linguistic personality, the creator of the image of the world. The phenomenon of language personality was studied by: G. Bogin developed a model of language personality as a person who is ready to produce speech actions, to create speech products; Y. Prokhorov identified and studied the features of speech and speech personality; T. Snytko considered the differences in the definition of the concept of "linguistic personality" of Western and Eastern cultures; V. Karasyk introduced the concept of "dictionary language personality"; O. Bilyaev researched the concept of "national-linguistic personality"; L. Matsko and S. Yermolenko defined a nationally-conscious Ukrainian-speaking personality; L. Skuratovsky studied the spiritual linguistic personality and others $[2 ; 5]$.

In psycholinguistics, intercultural communication, methodology of teaching foreign languages is developing as an independent direction as the formation of "secondary language personality". In particular, M. Kolpakova, O. Leontovych, I. Khaleeva and $\mathrm{K}$. Khitryk consider the secondary linguistic personality as one that masters another "linguistic picture of the world", which makes it possible to understand the new culture.

Scientist Yuri Karaulov identifies three levels of language personality depending on the structure and participants: 1. Verbal-semantic level, which contains lexical and grammatical means used by the individual. 2. Cognitive level, which unites the cognitive structures that form the picture of the world of the individual. 3. Pragmatic level, which covers the intentions and motives of the individual. [1, p. 230].

Quite often, linguistic explorations explore the concept of linguistic personality in relation to the concept of "ideology", which is reflected in the author's choice of speech material, stylistic devices and means 
of expression [10, p. 223]. The ideological style of the writer is explored by identifying its authorial features, compliance or non-compliance with the traditional principles of storytelling, ie all that shapes his individual authorial style. To highlight and emphasize the main features of the writer's ideology a person should distinguish a system of speech that were used by author to provide successful realization of its communicative purpose [11, p. 12].

Ideostyle is a way of reflecting the author's inner world, which demonstrates the author's understanding of the problems that concern him. It is characterized by the use of stylistic devices, new concepts, stylistically marked vocabulary to express the semantic and emotional content of the text. Thus, the linguistic personality of the author is an important component in understanding his work, his artistic discourse because of thought and speech activity, which reflects his worldview, his author's picture of the world.

Conditions of rational practical argumentation in the process of analysis, discussion and use of foreign artistic discourse in the process of learning a foreign language is an impact factor not only for increasing awareness of the author's worldview, but also as a factor to increase students' motivation in the long run. Some of these rules formulate general requirements for reasonable reasons, which are important in the conduct of dialogues and include regardless of the theory of discourse: freedom from contradictions, universalization in the sense of consistent use of predicates, linguistic and conceptual clarity, empirical truths, consideration of consequences and assessment [6, p. 44-47].

Conclusions. Artistic discourse is a multifunctional and multifaceted phenomenon of modern linguistics, which with the right methodological support in use is a factor in increasing the positive motivation of students to learn a foreign language. One of the aspects is the formation and improve- ment of the secondary linguistic personality through the perception of the reflection of the author'sworldview, which has a significant impact and leaves a wide field for further research. Our research has shown that the concept of "artistic discourse" has a significant number of definitions and a growing number of aspects, which leaves it a relevant phenomenon of the linguistic present $[5 ; 8 ; 10]$.

In the study of artistic discourse in foreign sources, we should follow a combined discourse analysis, as one of the main tasks of combined discourse analysis. That is constructive critique of discursive practice, which in the context of learning a foreign language and the formation of secondary language personality creates a suitable basis for further development and firstly it concerns the artistic discourse.

Critique of dominant discourses, according to M. V. Jorgensen and L. J. Phillips, opens opportunities for new combinations of discursive field elements, for reinterpretations of what is supposedly self-evident, and hence for the emergence of new knowledge [9].

The classifications of discourse theories we have considered confirm the fact that there are no sectoral or object constraints for discourse theories. Numerous theories of discourse are in polyparadigmatic, multidisciplinary direction, which is developing intensively with the methodically balanced use of results and materials.

Prospects for further scientific research include complex and narrow-scale studies of discourse theories and their methodological bases on various platforms of the Internet and works of art (movies, TV series, literary works, etc.). Particular emphasis in the context of our study should be placed on the study of discourse theories subordinated to the improvement of selected material for the educational process of language acquisition and aimed at increasing student motivation to learn a foreign language in particular.

\section{References:}

1. Бехта I. А. Дискурс наратора в англомовній прозі. Київ : Громада, 2004. 328 с.

2. Карасик В. И. Языковой круг: личность, концепты, дискурс. Москва : Гнозис, 2004. 390 с.

3. Переломова О. С. Лінгвокультурні коди інтертекстуальності українського художнього дискурсу: діахронічний аспект : монографія. Суми : Вид-во СумДУ, 2008. 208 с.

4. Лабунець Ю. О. Використання інтертекстуальності творів Дж. Р. Р. Толкіна у вихованні моральної особистості. Первый независимый научный вестник. Київ, 2015. № 1. Ч. 1. С. 118-120.

5. Лабунець Ю. О. Самоосвіта в контексті становлення вторинної мовної особистості майбутнього вчителя іноземної мови. Вісник психології і педагогіки : зб. наук. пр. / Педагогічний інститут Київського університету імені Бориса Грінченка, Інститут психології і соціальної педагогіки Київського університету імені Бориса Грінченка. Випуск 11. Київ, 2013. URL: http://www.psyh.kiev.ua.

6. Alexy R. Problems of Discourse Theory. Critica. 1988. № 20. P. 43-65. 
7. Labunets Y. Formation of future teacher's leadership qualities through learning a foreign language / N. Kosharna, Y. Labunets, O. Sytnyk. Advances in Social Science, Education and Humanities. Atlantis Press, 2019. Research Issue 318. p. 293-298. ISSN 2352-5398.

8. Lakoff R. Persuasive discourse and ordinary conversation, with examples of advertising. Analyzing discourse: text and talk / Ed. by D. Tannen. Washington : Georgetown University Press, 1982. P. 25-42.

9. Leist A. Diesseits der 'Transzendentalpragmatik': Gibt es sprachpragmatische Argumente für Moral? Zeitschrift für philosophische Forschung. 1989. № 43. S. 301-317.

10. MacCormick N. Moral Disestablishment and Rational Discourse / N. MacCormick. Recht und Moral. Ed. Heike Jung, Heinz Müller-Dietz, and Ulfrid Neumann. Baden-Baden : Nomos, 1991. S. 219-231.

11. Searle J. Conversation. Amsterdam, Philadelphia : John Benjamins Publishing Company, 1989. P. 7-29.

\section{Лабунець Ю. О. ВПЛИВ ХУДОЖНЬОГО ДИСКУРСУ НА ФОРМУВАННЯ МОТИВАЦЇ̈ СТУДЕНТІВ ДО ВИВЧЕННЯ ІНОЗЕМНОЇ МОВИ ЧЕРЕЗ ВІДОБРАЖЕННЯ АВТОРСЬКОЇ КАРТИНИ СВІТУ}

У статті проаналізовано визначення, особливості та основні характеристики дискурсу загалом та зокрема художнього дискурсу, які могли б бути використані для вивчення іноземної мови. Зокрема, автором побіжно розглянуто природу художнього дискурсу та його когнітивний $і$ комунікативний аспекти. Цей тип художнього дискурсу у аспекті впливу на мотиваційну сферу вторинної мовної особистості автором трактується як розумово-комунікативна взаємодія між автором і читачем, втілена в текстах художніх творів. Автор вбачає значний вплив дискурсу на мотиваційні прочеси картини світу людини, $і$ в контексті художнього дискурсу ми зазначаємо його вплив саме через відображення авторської картини світу на формування позитивної мотивації (як зовнішньої, так і внутрішньої) націленість на сприймання навколишньої дійсності у контексті іншомовної освіти. У статті відображено проблему впливу художнього дискурсу через представлення світогляду автора з мотиваційного погляду. Основні підходи до вивчення дискурсу розглядаються з кількох ракурсів. Використання впливу художнього дискурсу як потужного впливу на формування компетентності студентів з іноземноїмови для свідомого набуття компетенції іноземноїмови та формування вторинної мовної особистості - ие сучасна можливість сприяти навчанню мови, особливо для прочесу вивчення іноземних мов. У прочесі дослідження художнього дискурсу іноземних джерел варто дотримуватись комбінованого дискурс-аналізу як найоптимальнімого підходу у контексті позитивного впливу на мотивачійну сферу вторинної мовної особистості. Визначено та обговорено зростання мотивації до вивчення иільової мови, для иього необхідне використання прикладів іноземного художнього дискурсу. Дані збираються з емпіричного дослідження за допомогою методу залученого спостереження, інтерв'ю та років роботи старшим викладачем кафедри іноземних мов і методик їх навчання. 3 иього погляду автор акиентував увагу на важливості розуміння стратегій художнього дискурсу автора як сильного чинника впливу на мотивацію до самовдосконалення.

Ключові слова: дискурс, художній дискурс, іншомовний художній дискурс, відображення авторської краӥни світу, вторинна мовна особистість, мовна особистість автора, мотивачія до вивчення іноземної мови. 